\title{
Taxation of Debe Collection and Cancellation
}

\author{
Richard A. Wilson*
}

HE PURPOSE of this article is to examine and analyze some of the income

1 tax consequences arising from the payment, collection, compromise or cancellation of contractual rights and obligations. Several common factual situations will be discussed, and under each heading the tax position of the creditor and the debtor will be distinguished.

In the interests of more detailed study of a fairly limited subject matter, factual situations involving the foreclosure of mortgages and repossessions under installment sale or deferred payment contracts are not discussed. The author defers to the numerous sources in which those special problems are ably treated. ${ }^{1}$

\section{I}

\section{THE CREDITOR}

\section{A. General Rule}

The black letter rule in this area is that collections by the creditor up to the amount of his basis for the contractual obligation constitute a return of capital, but that collections in excess of basis constitute ordinary income. $^{2}$ Capital gain or loss treatment requires a "sale or exchange"3 or a statutory substitute therefor, ${ }^{4}$ and the courts have been consistent in holding that, from the standpoint of the creditor, the collection of a contractual obligation does not constitute a "sale or exchange." "Sale or exchange" implies a reciprocal transaction-one in which both parties dispose of property and receive other property in return. ${ }^{6}$ Collection of an obligation

* Member, San Francisco Bar.

1 E.g., Anderson, Tax Factors in Real Estate Operations (1960); Anderson, Tax Planning of Reat Estate (Ali-ABA Joint Comm. on Legal Educ., 1957).

2 Gamble v. Commissioner, 242 F.2d 586 (5th Cir. 1957); Ogilvie v. Commissioner, 216 F.2d 748 (6th Cir. 1954), affirming per curiam 20 T.C. 734 (1953); Osenbach v. Coinmissioner, 198 F.2d 235 (4th Cir. 1952).

8 INT. REv. CODE OF 1954, \$\$ 1202, 1222.

$\$ E . g .$, IvT. REv. CODE OF 1954, \$\$ 1232, 1235, 1241.

6 See, e.g., Milliken v. Commissioner, 196 F.2d 135 (2d Cir. 1952), cert. denied, 344 U.S. 884 (1952), rehearing denied, 344 U.S. 910 (1952); Bingham v. Commissioner, 105 F.2d 971 (2d Cir. 1939). For a recent case in point, see Ralph A. Boatman, 32 T.C. 1188 (1959).

6 Helvering v. William Flaccus Oak Leather Co., 313 U.S. 247 (1941); Trenton Cotton Oil Co. v. Commissioner, 147 F.2d 33 (6th Cir. 1945), rehearing denied, 148 F.2d 208 (6th Cir. 1945). Cf. Helvering v. Haminel, 311 U.S. 504 (1941); Commissioner v. Peterman, 118 F.2d 973 (9th Cir. 1941). 
is said to extinguish it pro tanto, leaving nothing in the nature of property which survives the transaction and which is capable of being transferred to the debtor. Therefore, there is no "sale or exchange." However, there is a "disposition" of property when a claim is relinquished upon payment, resulting in ordinary income to the creditor to the extent that payments received exceed his basis for the claim. ${ }^{9}$

The above rule may apply also with respect to losses sustained by the creditor. It has been stated that "the voluntary cancellation or forgiveness of indebtedness does not give rise to a deductible loss." 10 However, this statement requires qualification. It refers to a case in which the claim compromised or forgiven is not worthless. ${ }^{11}$ If the claim is worthless, the creditor who accepts partial payment in full satisfaction thereof sustains a loss measured by the difference between his basis and the payment received in compromise. ${ }^{12}$ However, the deductibility of a loss sustained by the creditor is governed by the bad debt provisions of the Internal Revenue Code. ${ }^{13}$ Non-business bad debts are treated as short term capital losses, ${ }^{14}$ whereas business bad debts are ordinary losses deductible in full..$^{15}$

Variations on this loss rule may exist if the creditor and the debtor stand in a shareholder-corporation relationship. A compromise or forgiveness by a shareholder-creditor of his claim against his corporation ordinarily constitutes a contribution to the capital of the corporation..$^{16}$ Accordingly, no bad debt deduction is realized by the stockholler-creditor, but the basis of his stock in the debtor corporation is increased in an amount

7 Cases cited note 5 supra.

8 INT. Rev. CoDE of 1954, \& 1001.

9 Hatch v. Commissioner, 190 F.2d 254 (2d Cir. 1951) ; Herbert's Estate v. Commissioner, 139 F.2d 756 (3d Cir. 1943), cert. denied, 322 U.S. 752 (1944); Helvering v. Roth, 115 F.2d 239 (2d Cir. 1940).

${ }^{10}$ Johnson, Drake \& Piper, Inc., 27 B.T.A. 585, 588 (1933), aff'd, 69 F.2d 151 (8th Cir. 1934), cert. denied, 292 U.S. 650 (1934).

11 Furthermore, the Commissioner has ruled that a mortgagee realizes a deductible loss upon the compromise of a purchase money mortgage debt even though the debtor is solvent and there has been no decline in the value of the encumbered property. I.T. 4018, 1950-2 Cum. Butz. 20.

12 Commissioner v. Sisto Financial Corp., 139 F.2d 253 (2d Cir. 1943). If the creditor's basis for the claim is less than the amount accepted in compromise, the difference is ordinary income. See Matilda S. Puelicher, 6 T.C. 300 (1946).

13 INT. Rev. CODE OF 1954, \&166. Under certain circumstances, however, the creditor's loss may be a business expense deductihle as such rather than a bad deht. See West Coast Securities Co., 14 T.C. 947 (1950), acq., 1950-2 Cum. Buxr. 4; Lalı Estates, Inc., 13 T.C. 811 (1949), acq., 1950-1 CuM. Butu. 3.

14 INT. Rev. CODE OF 1954, \& 166 (d).

15 Id. \& 166(a).

${ }^{16}$ Treas. R'eg. § 1.61-12(a) (1957); Pancoast Hotel Co, 2 T.C. 362 (1943), acq., 1943 CUM. BULL. 18. 
equal to his basis of the forgiven claim. ${ }^{17}$ However, it has been held that the forgiveness gives rise to a bad debt deduction rather than a capital contribution if the corporate debtor is insolvent at the time. ${ }^{18}$

In the reverse situation, a compromise or forgiveness by a corporate creditor of its claim against its shareholder-debtor is treated as a corporate distribution. ${ }^{19}$ Accordingly, no gain or loss is recognized to the corporate creditor even though its basis for the claim varies from the amount accepted in compromise. ${ }^{20}$

\section{B. Section 1232(a) (1)}

The Internal Revenue Code provides specifically ${ }^{21}$ that, as to the creditor, the "retirement" of bonds, debentures, notes or other evidences of indebtedness issued by a corporation constitutes an exchange of the obligation, giving rise to capital gain or loss. ${ }^{22}$ The word "retirement" is given its ordinary meaning. Payment in full of the corporate obligation obviously constitutes a retirement thereof. Furthermore, partial payment accepted by the creditor as full satisfacion constitutes a retirement of the obligation within the meaning of the section. ${ }^{23}$ It is not necessary that the full amount of the obligation be paid at one time; partial payment constitutes partial retirement of the obligation. ${ }^{24}$

Thus the general rule is that collections which are either greater or less in amount than the creditor's basis for the obligation give rise to ordinary, rather than capital, gain or loss. ${ }^{25}$ However, if the issuer of the obligation

17 Johnson, Drake \& Piper, Inc., 27 B.T.A. 585, 588 (1933), affd, 69 F.2d 151 (8th Cir. 1934), cert. denied, 292 U.S. 650 (1934). Quaere as to whether this rule would apply to a nonstockholder creditor who accepted stock of the debtor corporation in compromise of his claim. Cf. text following note 154 infra.

18 Giblin v. Commissioner, 227 F.2d 692 (5th Cir. 1955) ; Deeds v. Commissioner, 47 F.2d 695 (6th Cir. 1931).

19 See text following note 155 infra, for the effects on the debtor of such a transaction.

20 INT. REv. CODE OF 1954, $\$ 311$ (a). As provided in $\$ 311(\mathrm{a})$, however, there is one special situation where loss may be recognized and three where gaim may be recognized. See INT. REv. CoDE of 1954, $\$ 311$ (b), 311(c), 453(d). Note that gain recognized under $\$ 453$ (d) may, under the proper facts, be capital gain.

21 INT. Rev. Code OF 1954, § 1232 (a) (1).

22 This assumes that the claim is a capital asset in the hands of the holder thereof. Note that $\$ 1232$ (a) (1) applies to obligations issued hefore January 1,1955 only if they were issued with interest coupons or in registered form, or if they were in such form on March 1, 1954.

Section 1232 (a) (2) provides, for years governed by the 1954 Code, ordinary income treatment for the portion of the proceeds from the sale or exchange of obligations covered by $\S 1232$ which is allocable to original issue discount. For pre-1954 Code law, compare Commissioner v. Caulkins, 144 F.2d 482 (6th Cir. 1944), with Commissioner v. Morgan, 272 F.2d 936 (9th Cir. 1959). This subject is beyond the scope of this article.

23 Edith K. Timken, 6 T.C. 483 (1946), acq., 1946-2 Cusr. Bunc. 5.

24 Ibid.

25 But nonbusiness bad debts are treated as short-term capital losses. See text at note 14 
happens to have been a corporation, any disparity between collections and basis will result in capital gain or loss to the creditor.: ${ }^{: 8}$ In view of this distinction between certain corporate and non-corporate obligations-a disparity which seems difficult to justify-it may ${ }^{27}$ be wise for a creditor to insist that his debtor be a corporation, even if one must be formed specifically for that purpose.

\section{The "tax benefit rule"}

A further variation on the general rule stated above is embodied in the so-called "tax benefit rule." This rule provides that a recovery with respect to a loss or expense taken as a deduction in a prior year constitutes income in the year of the recovery to the extent that the prior deduction resulted in a tax benefit. Conversely, it provides that no income is realized from the subsequent recovery to the extent that the prior deduction did not result in a tax benefit. This rule is codified in the Internal Revenue Code $^{28}$ with regard to certain specified items, but the courts have held that this section is not exclusive and that the tax benefit rule applies to recoveries ${ }^{29}$ with respect to all items previously deducted. ${ }^{30}$

The tax benefit rule provides merely that income is realized at the time of the recovery to the extent that the prior deduction resulted in a tax benefit. It does not tell us whether this income is ordinary or capital gain in nature. However, as might be expected in view of the general rule with respect to collections of contractual obligations, it has been held that the subsequent recovery which constitutes income under the tax benefit rule

${ }^{28}$ See note 22 supra. But the portion of the retirement proceeds which represents accrued interest is taxable as such. Allen Tobey, 26 T.C. 610 (1956), acq., 1956-2 Corr. BuLL. 8; Warner A. Sbattuck, 25 T.C. 416 (1955).

27 This statement is qualified because there are three possible types of losses arising from collection or compromise: (1) a capital loss under 81232 (a) (1), which capital loss may be either long or short term; (2) a business bad debt, deductible in full; and (3) a non-business bad debt, deductible as a short term capital loss. See text following notes 13 and 22 supra.

28 INT. REv. Cone or 1954, 8111 , dealing with recovery of bad debts, prior taxes and delinquency amounts.

29 This limitation on the amount of recovery includible in incorne does not apply in favor of amounts previously deducted for depreciation, depletion or amortization. See Treas. Reg. 118, 839.22 (b) (12)-1 (1953); Douglas v. Commissioner, 322 U.S. 275 (1944); Louisiana Delta Hardwood Lumber Co., 12 T.C. 576 (1949), aff'd per curiam, 183 F.2d 189 (5th Cir. 1950).

30 Dobson v. Commissioner, 320 U.S. 489 (1943), rekearing detied, 321 U.S. 231 (1944); T. O. McCamant, 32 T.C. 824 (1959), acq., 1960-2 INT. REv. Box.. 6; Birmingham Terminal Co., 17 T.C. 1011 (1951), acq., 1952-1 Cosc. BuLL. 1.

Quaere whether insolvency of the creditor at the time of the recovery would prevent taxation even of the amount which resulted in a prior tax benefit. For discussion of the insolvency rule as applied to debtors, see text folloving note 85 infra. Compare also the theory that release of a claim can be a tax-free gift to the debtor even though be realized a prior tax benefit. See text following note 101 infro. 
gives rise to ordinary income rather than capital gain. ${ }^{31}$ Presumably this would be true even though the prior deduction was for a capital loss, such as a non-business bad debt. In this connection, however, it must be remembered that the recovery constitutes income only to the extent of the prior tax beneit. If the tax benefit from the prior deduction was limited by the capital loss provisions, the amount of ordinary income includible in the year of recovery ${ }^{32}$ would be similarly limited. ${ }^{33}$

To illustrate the tax treatment of the subsequent recovery on a claim which previously had been written off as wholly or partially worthless, the following examples are presented.

(1). In 1957, corporation $A$ held a note of corporation $X$ with a basis and face amount of $\$ 10,0000^{34}$ The note became partially worthless in 1957 and $A$ took a $\$ 5,000$ bad debt deduction under section 166 (a) (2). $A$ 's gross income for 1957 was $\$ 2,500$, and the above bad debt was its only deduction. Therefore, only $\$ 2,500$ of the bad debt deduction resulted in a tax benefit to $A:^{35} \mathrm{~A}$ 's basis for the note now is $\$ 5,000 .^{36}$ In $1958 X$ pays the note in full. The tax treatment to $A$ of this payment is as follows: (i) $\$ 5,000$ is a tax-free recovery of basis; (ii) $\$ 2,500$ is a tax-free recovery of the portion of the prior deduction which did not result in a tax benefit; ${ }^{37}$ and (iii) $\$ 2,500$ constitutes ordinary mcome under the tax benefit rule. Even though the note is an obligation covered by section 1232 (a) (1), the

31 Dobson v. Commissioner, 320 U.S. 489 (1943), rehearing denied, 321 U.S. 231 (1944). This is so even if a corporate obligation covered by $81232(\mathrm{a})(1)$ is involved. First National Bank of Lawrence County, 16 T.C. 147 (1951). The reason is that the claim ceases to be a capital asset to the extent that its basis bas been written off with a tax benefit. See text at note 38 infra.

82 The taxable amount of the recovery is included in the year of recovery. This principle is modified as to certain special situations by the spread-back provisions of INT. REv. CODE OF 1954, $\$ 81301-06$. Extensive discussion of these provisions is beyond the scope of this paper.

33 See Treas. Regs. $\$ \$ 1.111-1$ (a)(4), (b)(2) (ii) (1956). The amount of recovery required to be included in income under the tax benefit rule is the same as that portion of the prior deduction which caused a reduction in tax for the prior year. INT. REv. CODE OF 1954, $\S 111$ (b) (4); Treas. Reg. $\$ 1.111-1$ (b) (2) (1956); Rothensies v. Electric Storage Battery Co., 329 U.S. 296 (1946). However, the Court of Claims has held, on equitable grounds, that the amount of the recovery which must be included in income is an amount which will yield the same tax as the amount by which the prior year's tax was reduced on account of the deduction. Perry v. United States, $142 \mathrm{Ct}$. Cl. 7, $160 \mathrm{~F}$. Supp. 270 (1958). The Service has announced that it will not follow this case since it is in conflict with other authority. Rev. Rul. 59-141, 1959-1 Cum. BuLc. 17. Compare the Perry case, with Int. Rev. Code of 1954, \$\$ 1301-06.

84 Assume that the note was originally a capital asset in the hands of $A$ and that it is an obligation of the type described in $\$ 1232$ (a) (1) issued after December 31, 1954. Assume also that the note is not a "security" as defined in INT. REv. CODE of 1954, $\$ 165(\mathrm{~g})(2)$ (C).

85 See note 33 supra, for the meaning of "tax benefit."

36 Basis is reduced by the amount charged off as a bad debt. See Merchants National Bank v. Umited States, 57-1 U.S. Tax Cas. \9380 (D. Kan. 1956).

87 See INT. REv. CODE OF 1954, 8111 (a); Mercliants National Bank v. United States, 57-1 U.S. Tax Cas. $₫ 9380$ (D. Kan. 1956). 
$\$ 2,500$ allocable to the prior tax benefit in ordinary income rather than capital gain, because the note is no longer a capital asset to the extent that the prior deduction resulted in a tax benefit. ${ }^{38}$

(2). Same facts as example (1) except that the note has a basis of $\$ 8,000^{39}$ and face amount of $\$ 10,000$. After the $\$ 5,000$ deduction, $A$ 's basis for the note will be $\$ 3,000$. The $\$ 10,000$ received in 1958 will be taxed as follows: (i) $\$ 3,000$ is a tax-free recovery of basis; (ii) $\$ 2,500$ is non-taxable under the tax benefit rule; (iii) $\$ 2,500$ is ordinary income under the tax benefit rule; and (iv) $\$ 2,000$, the difference between original basis and face value, will be capital gain. ${ }^{40}$ The reason that item (iii) is ordinary income while item (iv) is capital gain is that the note continues to be a capital asset except to the extent that the prior deduction resulted in a tax benefit. ${ }^{41}$

(3). Same facts as example (2) except that the maker of the note is not a corporation and section 1232 (a) (1) is therefore inapplicable. In this case $\$ 3,000$ will be tax-free recovery of capital and $\$ 2,500$ will be tax-free under the tax benefit rule, but the remaining $\$ 4,500$ will be ordinary income to $A .{ }^{42}$

The tax benefit rule by its terms deals only with recoveries made with respect to items deducted in a prior year. If no prior deduction was taken the taxation of payments received on a claim is not limited by this rule, but rather is governed by the rules discussed in other portions of this article. ${ }^{43}$ $D$. Claims having no ascertainable value-the open transaction rule

Still another variation on the general rule that collections in excess of basis give rise to ordinary income is the rule of Commissioner v. Carter. ${ }^{44}$ The Carter case held that if contractual rights distributed to a shareholder in liquidation have 10 ascertainable fair market value at that time, subsequent collections made by the shareholder with respect to such rights constitute capital gain rather than ordinary income. Normally when a corporation is liquidated and its assets distributed in kind, the shareholder

38 First National Bank of Lawrence County, 16 T.C. 147 (1951).

39 Assume that $A$ purchased the note from the original holder for $\$ 8,000$.

40 See First National Bank of Lawrence County, 16 T.C. 147 (1951); Anne P. Humphrey, $5 \mathrm{CCH}$ Tax Ct. Mem. 21, 30 (1946). If the difference between basis and face value represented original issue discount within the meaning of $\$ 1232$ (a) (2), that amount would be ordinary income. See note 22 supra.

41 See First National Bank of Lawrence County, 16 T.C. 147 (1951). Cf. Merchants National Bank v. United States, 57-1 U.S. Tax Cas. II 9380 (D. Kan. 1956).

$42 \$ 2,500$ ordinary income under the tax benefit rule and $\$ 2,000$ under the general rule of collections on contractual ohligations.

43 Helvering v. Roth, 115 F.2d 239 (2d Cir. 1940); Estate of Ernst Zobel, 28 T.C. 885 (1957).

44 $170 \mathrm{~F} .2 \mathrm{~d} 911$ (2d Cir. 1948). The rule of this case was in turn derived from Burnet $\mathrm{v}$. Logan, 283 U.S. 404 (1931). See note 49 infra. 
realizes capital gain or loss in the amount of the difference between the basis of his stock and the fair market value of the assets received. ${ }^{45}$ These assets then have a basis to the shareholder equal to their fair market value at the time of distribution. ${ }^{46}$ If contractual claims are received in the liquidation distribution, subsequent collections in excess of basis will, under the general rule, give rise to ordinary income. ${ }^{47}$

Since basis to the shareholder depends upon the fair market value of the distributed asset, no basis can be assigned to a contractual claim which cannot be valued. In such a case the liquidation distribution is deemed to be an open transaction and subsequent collections on the claim which had no ascertainable value are related back to and take on the same tax character as the liquidation distribution. ${ }^{48}$

This "open transaction" theory is not limited to claims distributed in a corporate liquidation. It applies to any situation where the basis of a contractual claim is dependent upon its fair market value and that value cannot be ascertained because of the highly contingent nature of the creditor's rights. ${ }^{49}$ In such situations the transaction whereby the creditor acquired the claim will remain open and subsequent collections will take on the same tax character as the original transaction. If the original transaction was capital in nature, the creditor will be entitled first to recover his basis for the property which he exchanged for the contractual claim, ${ }^{50}$ and collections in excess thereof will constitute capital gain.

The open transaction rule of the Carter case is phrased in terms of contractual claims which have "no ascertainable market value." which probably existed all along ${ }^{52}$ was recently drawn between no ascertainable market value and no market value. ${ }^{53}$ This distinction is illustrated by Miller $v$. United States, ${ }^{54}$ in which case the court determined that the open

45 See INT. REv. CoDE of 1954, §§331 (a) (1), 1001. This is assuming that the stock is a capital asset in the hands of the shareholder.

46 INT. Rev. Code of 1954, § 334(a).

47 Miller v. United States, 262 F.2d 584 (6th Cir. 1958), affrming per curiam 155 F. Supp.

767 (W.D. Ky. 1957); Osenbach v. Commissioner, 198 F.2d 235 (4th Cir. 1952).

48 See note 45 supra. Compare the open transaction theory with the rule of Arrowsmith v. Commissioner, 344 U.S. 6 (1952).

49 See Burnet v. Logan, 283 U.S. 404 (1931), which involved the sale of stock in exchange for a contract providing for payments based on production of a coal mine.

The Coinmissioner has recognized the open transaction rule, but has stated that cases of contractual clains having no ascertainable fair market value are "rare and extraordinary." Rev. Rul. 58-402, 1958-2 Cum. BuLI. 15.

50 See Treas. Reg. § 1.453-6(a) (2) (1958).

51 Commissioner v. Carter, 170 F.2d 911, 913 (2d Cir. 1948).

52 See cases cited at note 43 supra. But note that the regulations dealing with deferred payment sales of real property speak of claims having "no fair market value." Treas. Reg. $\S 1.453-6(a)(2)$ (1958).

53 American Bar Association, Section of Taxation, Bulletin, Oct. 1959, p. 32.

54262 F.2d 584 (6th Cir. 1958), affrrning per curian 155 F. Supp. 767 (W.D. Ky. 1957). For earlier proceedings in the same case, see 235 F.2d 553 (6th Cir. 1956), reversing and re- 
transaction rule was mapplicable to collections made on second mortgage notes acquired as a liquidation distribution because the notes had no fair market value-i.e., a zero value-when received. Subsequent collections on the notes were lield to give rise to ordinary income rather than capital gain. It is noteworthy that in the Miller case the taxpayer probably would have been better off had he agreed originally with the Commissioner's contention that the notes liad a market value equal to twenty-five percent of their face amount. His capital gain from the liquidation would have been increased accordingly, but le now would have a cost basis for the notes which could be recovered tax-free, thereby reducing the amount of ordinary income derived froin collections.

Since the notes had a zero value, however, they have a zero basis and all collections thereon will give rise to ordinary income. In such a situation the taxpayer might be wise to sell the notes, reporting the entire proceeds as capital gain. ${ }^{55}$

The Commissioner himself has stated that contracts having no ascertainable market value are "rare and extraordinary." Even though one may agree with the logic of the Miller case-i.e., that no market value differs from no ascertainable market value-it is difficult to believe that the second mortgage notes involved had a market value of zero. ${ }^{57}$ Perhaps the Miller case merely stands for the proposition that an ordinary note always has an ascertainable market value.

In the recent case of Estate of Abraham Goldstein, ${ }^{68}$ a corporation liquidated and distributed its assets, which included insurance renewal commission contracts. The pertinent issue was whether subsequent collections by the shareholder constituted capital gain under the open transaction theory. The Tax Court held that the contracts had an ascertainable fair market value at the time of the liquidation and that subsequent collections in excess of that value therefore constituted ordinary income. The case is interesting for two reasons. First, in finding that the contracts had an ascertainable market value, the court relied heavily upon the fact that insurance companies have tables which can be used in calculating the actuarial value of such contracts. Although other factors supported the court's finding that the contracts could be valued, ${ }^{59}$ this reliance upon actuarial tables is unfortunate. The court seems to have confused actuarial value with market value. Second, after finding that the contracts could be valued, the

55 This assumes, of course, that the notes are capital assets in the hands of the taxpayer.

56 Rev. Rul. 58-402, 1958-2 Cuns. Burr. 15.

57 It must be pointed out, however, that the taxpayer in Miller argued that the notes had no fair market value. This was interpreted to mean zero value.

5833 T.C. 1032 (1960).

58 There was evidence of at least a limited market for the sale of insurance renewal commission rights. 
valuation figure was set by resort to the Cohan rule ${ }^{60}$ on the ground that there was insufficient evidence in the record upon which to base an accurate finding of market value. One may only speculate as to why it was found necessary to use the Cohan rule to set the value when the record probably contamed the actuarial tables ${ }^{81}$ which helped to persuade the court that the contracts had some value in the first place.

\section{II}

\section{THE DEBTOR}

\section{A. Satisfaction in Full-General Rule}

Generally, no gain or loss is realized by a debtor when he satisfies an obligation with cash. ${ }^{62}$ Since there is no gain or loss, it is unnecessary to determine whether the transaction constitutes a sale or exchange as to the debtor. However, if the debtor uses property other than cash to satisfy the obligation or if he is discharged by the creditor for less than full payment, he may realize gain or loss from the transaction.

If the debtor satisfies his obligation with property the basis of which is equal to its fair market value, the tax results are the same as they would be had cash been paid to the creditor. ${ }^{63}$ But the debtor realizes gain or loss if he satisfies the obligation with property having a basis to him which differs from its fair market value. ${ }^{64}$ The amount of the gain or loss is the difference between the basis and fair market value of the property used to satisfy the obligation. ${ }^{.5}$ In view of the general rule concerning collections made by a creditor, one would expect the gain or loss realized by the debtor to be ordinary income or loss. However, the rule is that the debtor who transfers property to the creditor in satisfaction of his obligation is engaging in a sale or exchange. ${ }^{68}$ The rationale of the general rule that the creditor who receives payments on his claim is not participating in a sale or exchange is that a sale or exchange requires the receipt and transfer of

60 Cohan v. Commissioner, 39 F.2d 540 (2d Cir. 1930).

61 The reported decision does not disclose whether the actuarial tahles vere in the record.

62 The cash would have a basis equal to value and it is presumed that the obligation has a value equal to the amount paid in full satisfaction thereof. See Commissioner v. Mesta, 123 F.2d 986 (3d Cir. 1941), cert. denied, 316 U.S. 695 (1942). But see Commissioner v. Marshman, 279 F.2d 27 (6th Cir. 1960).

This rule does not apply if the debtor is a guarantor. Payment by a guarantor gives rise to a bad debt deduction. InT. REv. CoDE of 1954, \& 166(f); Treas. Reg. \& 1.166-8 (1959); Pułnam v. Commissioner, 352 U.S. 82 (1956).

63 See note 62 supra.

84 Kenan v. Commissioner, 114 F.2d 217 (2d Cir. 1940).

65 The value of the obhigation is presumed to be the same as the value of the property transferred in satisfaction thereof. See note 62 supre.

${ }^{86}$ Kenan v. Commissioner, 114 F.2d 217 (2d Cir. 1940). The character of the gain or loss realized from this sale or exchange is dependent upon the character of the transferred property. 
property by both parties and nothing passes from the creditor to the debtor because the claim is extinguished pro tanto by payment. ${ }^{67}$ In view of the requirement that a sale or exchange must involve a reciprocal receipt and transfer, ${ }^{\text {e8 }}$ it is not easily understood how the satisfaction of a contractual obligation can be a sale or exchange as to the debtor but not the creditor. The explanation that has been offered for the distinction is that the transaction is treated as though the debtor had first sold his property and then used the proceeds to satisfy his obligation. ${ }^{69}$

\section{B. Compromise or Cancellation}

Compromise or cancellation of an obligation is to be distinguished from satisfaction. The latter refers to payment in full, whereas the former refers to a situation in which the debtor is discharged by the creditor for something less than full payment. The tax consequences to the debtor may vary considerably in the two instances.

\section{Cancellation Without Transfer of Property}

The general rule is that the debtor realizes income when his obligation is compromised or cancelled, the amount of the income being measured by the difference between the amount paid and the full amount of the discharged obligation. ${ }^{70}$ Of course, if nothing is paid for the discharge, the income is equal to the full amount of the obligation. The theory for attributing income to the discharged debtor is that he has realized a negative gain by the reduction of his liabilities-his net worth has been increased by the compromise or cancellation. ${ }^{71}$

Whereas gain realized by the debtor from satisfaction of an obligation is, under the general rule, capital gain if a capital asset is involved, it seems that the gain attributed to the debtor when his obligation is compromised is ordinary income. ${ }^{72}$ The debtor who satisfies his obligation by transferring

67 See text at note 6 supra.

68 Text at note 6 supra.

${ }^{68}$ See Peninsula Properties Co., 47 B.T.A. 84 (1942), acq., 1942-2 Cun. Butr. 14; Carlisle Packing Co., 29 B.T.A. 514 (1933); E. F. Simms, 28 B.T.A. 988 (1933).

70 See United States v. Kirby Lumber Co., 284 U.S. 1 (1931).

71 Ibid.

72 This is not clear, since the numerous cases on cancellation of indebtedness income usually fail to consider whether the gain is ordinary or capital in nature. But Peninsula Properties Co., 47 B.T.A. 84 (1942), acq., 1942-2 CuM. BuLc. 14, elearly implies that such gain is ordinary incoine if no property passes from the debtor to the creditor as part of the discharge. In the Peninsula Properties case the debtor was released from an obligation of some $\$ 52,000$ for a cash payment of $\$ 11,250$. The issue before the court was whether the amount discharged was incoine to the debtor who claimed that the insolvency rule applied (see text following note 86 infra). In rejecting the applicability of the insolvency rule the court stated that the ainount discharged was ordinary incoune to the debtor, although the character of any realized gain apparently was not in issue before the court. Id. at 93 .

Also to the effect that cancellation of indebtedness income is ordinary income, see 2 RAdkIN \& Jominson, Federal Income, Gift and Estate Taxation, ch.36, passim (1954). 
property to the creditor is treated as though he had first sold the property and then given the proceeds to the creditor in satisfaction of the obligation. ${ }^{73}$ By adopting this reasoning a sale or exchange is found and the debttor's gain or loss therefore is capital in nature if the transferred property was a capital asset. However, this reasoning does not fit a transaction in which the debtor is discharged upon compromise or cancellation of his obligation without the transfer of property ${ }^{74}$ to the creditor. There is no property which can be treated as though it had first been sold by the debtor. Since no sale or exchange can be found, the gain realized by the debtor is ordinary income.

\section{Transfer of Property in Compromise}

It has just been seen that the debtor realizes ordinary income when his obligation is discharged by compromise or cancellation without the transfer of any property to the creditor. What is the tax result to the debtor if his obligation is compromised and discharged upon the transfer by him of property whose market value is less than the full amount of the discharged obligation? It is theoretically possible to divide the transaction into two parts. First, the debtor transfers to the creditor property of a certain value in satisfaction of that same amount of his obligation. Next, the creditor cancels the remainder of the obligation and discharges the debtor. Under this analysis the debtor would realize capital gain or $\operatorname{loss}^{75}$ to the extent of the difference between his basis for the transferred property and its market value, and he would realize ordinary income to the extent of the difference between the full amount of the obligation and the market value of the property transferred in compromise thereof.

The Commissioner has attempted just such a division of a compromise situation, but his efforts were rejected by the Board of Tax Appeals, now the Tax Court, in Peninsula Properties $\mathrm{Co}^{76}$ In that case the full amount of the obligation was some $\$ 182,000$, the debtor's basis for the transferred property was $\$ 100,000$ and its market value apparently was also $\$ 100,000$. The court lield tliat the transaction, on its facts, could not be divided into two parts and that the gain realized by the debtor arose from a sale or exchange and therefore was capital gain. In the absence of a successful argument $^{77}$ for dividing the transaction into a satisfaction of part and a cancellation of the balance of the obligation, the Peninsula Properties case stands

73 See text at note 69 supra.

74 As used, "property" does not include cash. See Peninsula Properties Co., 47 B.T.A. 84 (1942), acq., 1942-2 CuM. Buxx. 14. See also text at note 81 infra.

75 This assumes the presence of a capital asset.

7647 B.T.A. 84 (1942), acq., 1942-2 CuM. Buxx. 14

77 See 2 Research Institute of AMterica, Federai Tax Coordinator, II I-1310 (1960), citing the Peninsula Properties case. 
for the proposition that the debtor will realize capital gain or $\operatorname{loss}^{78}$ measured by the difference between the full amount of the discharged obligation and his basis for the transferred property.

Even though the above argument for dividing the compromise into two parts may be unsuccessful, there is another, perhaps more forceful, theory under which part of the debtor's gain would constitute ordinary cancellation of imdebtedness income. When a debtor satisfies an obligation by the transfer of a capital asset, he realizes capital gain or loss measured by the difference between his basis and the market value of the transferred property..$^{79}$ The reason is that the debtor is treated as though he had first sold the property and then satisfied his obligation with the proceeds.$^{80}$ Why is this same logic not applicable to a transfer of property in compromise and cancellation of the debtor's obligation? If the debtor is treated as though he had first sold the capital asset and then compromised his obligation with the proceeds, the difference between basis and value of the property would be capital gain or loss while the difference between the full amount of the discharged obligation and the proceeds of the fictitious sale of the property would be ordinary cancellation of indebtedness income. This is so because the Peninsula Properties case itself indicates that the transfer of cash in compromise of an obligation gives rise only to ordinary cancellation of indebtedness income. ${ }^{81}$

In spite of this theory, however, the Peninsula Properties case probably is good law. ${ }^{82}$ Its authority is bolstered by the many cases holding that the entire gain realized by a mortgagor who transfers the mortgaged property to the mortgagee in cancellation of the obligation is capital gain. ${ }^{83}$ Although the mortgage cases are often treated separately, the theory by which they find capital gain or loss seems equally applicable to any transfer of property in compromise and cancellation of an obligation.

It slould be noted that if the Peninsula Properties case is good law, the debtor who is negotiating a compromise with his creditor might $\mathrm{t}^{84}$ be wise

T8 This assumes a capital asset. A capital loss would be sustained if the debtor's basis exceeded the full amount of the obligation. Cf. Rogers v. Commissioner, 103 F.2d 790 (9th Cir. 1939), cert. denied, 308 U.S. 580 (1939).

T8 See text following note 66 supra.

80 See text at note 69 supra.

81 This phase of the case is discussed in note 72 supra.

${ }^{82}$ Note the Commissioner's acquiescence, published in 1942-2 Cux. Buxx. 14. But see Treas. Reg. $\$ 1.1017-1$ (b) (5) (1956), discussed in text following note 110 infra.

83 See Kaufman v. Commissioner, 119 F.2d 901 (9th Cir. 1941) ; Rogers v. Commissioner, 103 F.2d 790 (9th Cir. 1939), cert. denied, 308 U.S. 580 (1939).

84 The qualification results from the fact that the debtor might prefer to realize cancellation of indebtedness income and then elect under INT. REV. CODE OF 1954, \& 108 to defer recognition of that income by adjusting the basis of his property under INT. REv. CODE OF 1954, 81017 . See text at notes 107,115 , and following note 116 infro. 
to transfer a capital asset of relatively small value rather than giving cash to the creditor. In this manner the debtor could convert ordinary cancellation of indebtedness income into capital gain.

\section{The Insolvency Rule}

We have seen that the debtor whose obligation is discharged for less than full payment realizes income on the ground that his net worth has been increased by the compromise or cancellation. ${ }^{85}$ There are several exceptions to this rule, one of the most important being the insolvency rule. This exception provides that no income is realized by the debtor if he is insolvent ${ }^{86}$ both before and after the compromise or cancellation. ${ }^{87}$ The reason for attributing income to a solvent debtor when his obligation is cancelled is that his net worth has been increased just as if he had received some other income which is clearly taxable. This reasoming is equally applicable to an insolvent debtor whose deficit is reduced by the cancellation. Furthermore, insolvency is not a defense to taxation of other forms of income. ${ }^{88}$ Nevertheless, the courts hold that insolvency prevents the realization of income from cancellation of indebtedness.

As noted above, this rule apphes only if the debtor is insolvent both before and after the compromise or cancellation. A further refinement is provided by the cases which hold that if the cancellation makes the debtor solvent, he realizes income to the extent that his assets exceed his liabilities after the cancellation. ${ }^{89}$

It was seen earlier that the usual rule of ordinary income from cancellation of indebtedness does not apply if the debtor transfers a capital asset to the creditor as part of a compromise of his obligation. In such a case the entire transaction is deemed to be a sale or exchange as to the debtor and his gain qualifies for capital treatment. Since gain from the sale or exchange of property does not escape taxation merely because the seller is insolvent, ${ }^{90}$ one might expect that the insolvency rule would apply only to a pure cancellation and not to a case where the debtor transfers property as part of

85 Text at note 71 supro.

${ }^{88}$ Insolvency for this purpose means that market value of assets does not exceed liabilities. See Rev. Rul. 58-600, 1958-2 Cusx. Burx. 29.

87 Dallas Transfer \& Terminal Warehouse Co. v. Commissioner, 70 F.2d 95 (5th Cir. 1934); F. W. Sickles Co. v. United States, 90 Ct. Cl. 600, 31 F. Supp. 654 (1940); Astoria Marine Construction Co., 12 T.C. 798 (1949); Treas. Reg. \$ 1.61-12(b) (1957).

88 Parkford v. Commissioner, 133 F.2d 249 (9th Cir. 1943), affirming 45 B.T.A. 461 (1941), cert. deried, 319 U.S. 741 (1943). Cf. John McDevitt, Jr., 10 P-H B.T.A. Memo. Dec. 466 (1941).

89 Texas Gas Distributing Co., 3 T.C. 57 (1944), acq., 1944 Com. BuLc. 27; Lakeland Grocery Co., 36 B.T.A. 289 (1937).

90 Richard B. Gump, 10 P-H B.T.A. Mem. Dec. 89 (1941). Cf. Jobn McDevitt, Jr., 10 P-H B.T.A. Mem. Dec. 466 (1941). 
a compromise of his obligation. Such, however, is not the case. The insolvency rule was applied in Main Properties, Inc., ${ }^{\text {o1 }}$ in which case the insolvent debtor purchased its bonds with property the basis and market value of which were less than the face amount of the bonds. In that case the face amount of the bonds was $\$ 640,000$, the debtor's basis for the property was some $\$ 212,000$ and its market value was some $\$ 260,000$. Conceivably the court could have limited the application of the insolvency rule to the cancelled portion of the bonds- $\$ 380,000$-and held that the gain from the exchange of property- $\$ 48,000$ - was taxable in spite of the debtor's insolvency. ${ }^{92}$ The court, however, held that the insolvency rule prevented taxation of any of the debtor's gain from the transaction.

The insolvency rule applies only if there is a compromise or cancellation of the debtor's obligation. Insolvency does not prevent the taxation of gain realized by a debtor upon satisfaction of his obligation by means of transferring appreciated property to his creditor. ${ }^{93}$

A further variant on the rule that cancellation of indebtedness gives rise to income to the debtor is provided by certam provisions of the Internal Revenue Code and the Bankruptcy Act..$^{94}$ Regardless of the solvency of the debtor, no income is realized from the cancellation or reduction of his indebtedness under the following transactions: (1) a corporate reorganization confirmed under chapter $X$ of the Bankruptcy Act; (2) an "arrangeinent" or a "real property arrangement" confirmed under chapters XI and XII of the Act; or (3) a "wage earner's plan" confirmed under chapter XIII of the Bankruptcy Act. ${ }^{95}$ Furthermore, the Code provides $^{96}$ that no gain or loss is recognized from the cancellation or adjustment of indebtedness in a judicial insolvency reorgamization wlich involves the transfer of assets from one corporation to another.

If the provisions of the Bankruptcy Act are rebied upon by the debtor for the nonrecognition of cancellation of indebtedness income, he must submit to a corresponding adjustment to the basis of property retained by him. ${ }^{97}$ Thus the aim of these provisions is to postpone taxation of the cancellation of indebtedness mcome until the debtor is better able to incur such

914 T.C. 364 (1944), acq., 1945 CCM. BuLx. 5.

92 This argument apparently was not advanced by the Commissioner. However, such a division of a similar transaction was rejected in the Peninsula Properties case, discussed in text following note 76 suspra. See also note 104 infra.

93 Richard B. Gump, 10 P-H B.T.A. Mem. Dec. 89 (1941).

94 For discussion of these provisions, see 2 Rabin \& Johnson, Federal INcome, GIFT axd Estate Taxation, \$36.04 (1954); 2 Mertexs, Law of Federal Income Taxatiox, $\$ 11.23$ (1959).

85 Treas. Reg. $\$ 1.61-12$ (b) (1) (1957).

96 IFT. REV. CODE OP 1954, \$§ 371, 374.

07 Treas. Reg. $\$ \$ 1.1016-7,1.1016-8$ (1957). But see Ivt. REv. CODE of 1954, $\$ 1018$. 
a $\operatorname{tax} .{ }^{98}$ If, however, the debtor escapes taxation of the cancellation of indebtedness income because the transaction comes within the insolvency reorganization provisions of the Code, no corresponding basis adjustment is required. ${ }^{99}$ If the transaction whereby the obligation is compromised or cancelled does not come within any of the special statutory provisions discussed above but rather is governed by the insolvency rule, it is doubtful that the debtor would be required to adjust the basis of property retained by him merely because the cancellation income escaped taxation under that rule. ${ }^{100}$ Thus it seems that the debtor who has a choice would prefer, from the tax standpoint, not to rely upon the relief provisions of the Bankruptcy Act.

\section{Cancellation as a. Gift}

If the voluntary forgiveness by the creditor is motivated by a donative intent, the cancellation is a gift to the debtor and no income is realized by him..$^{101}$ In Helvering v. American Dental Co. ${ }^{102}$ creditors forgave accrued interest and rent owed them on the condition that the debtor pay the balance of the total rent due. The United States Supreme Court found that the release by the creditors was a gift and that therefore no taxable income was realized by the debtor even though a tax benefit had resulted from the previous accrual and deduction of the forgiven rent and interest.

In Commissioner v. Jacobson, ${ }^{103}$ the Court interpreted the American Dental case as involving the release of part of a claim for cash (the balance of the rent which the debtor was required to pay) and the balance for nothing, and distinguished such a case from one in which the creditor compromises his claim for the best price obtainable. ${ }^{104}$ In Jacobson the Court refused to find a gift where the debtor purchased his bonds at a discount from the bondholders, the facts being analyzed as the compromise of the obligations for the best price obtainable. Accordingly, the debtor was held to have realized cancellation of indebtedness income. In view of Jacobson

98 See text following note 116 infra, for discussion of the possibility that the nonrecognition and corresponding basis adjustment may result in converting ordinary income into capital gain when the assets whose bases are adjusted are later sold by the debtor.

99 INT. REv. CODE OF 1954, \$\$ 372, 373(b), 374(b).

100 See 2 Rabinn \& Jomnson, Federal Income, GifT and Estate Taxation \$ 36.02(3) (1954). Cf. INT. REv. Code of 1954, $\S 108,1017$, discussed in text following note 106 infra. 101 Helvering v. American Dental Co., 318 U.S. 322 (1943).

102 Ibid.

103336 U.S. 28 (1949).

104 In effect, the Jacobson Court said that the American Dental Court divided the transaction into two components-satisfaction of part of the obligation and release of the balance. Other courts have refused to make such a division of similar transactions. See text following notes 76 and 91 supra. 
and the subsequent lower court cases which have followed it, ${ }^{105}$ the rule of the American Dental case seems to be of limited application in the cancellation of indebtedness area.

\section{Election to Reduce Basis}

Section 108 of the Code provides that, if the debtor so elects, no income is recognized from the cancellation of an indebtedness for which the debtor is hable or subject to which he holds property if the indebtedness was incurred or assumed by a corporation or by an individual in connection with property used in his trade or business. In order to have the benefit of the election, however, the debtor inust consent to the reduction of the basis of his property ${ }^{108}$ by an amount equal to the income which otherwise would have been taxable to him because of the cancellation. ${ }^{107}$

The regulations provide for the manner in which the total basis reduction is allocated among various properties of the electing debtor. ${ }^{108}$ In general, the basis of the debtor's property is reduced in the following order: (1) property for the purchase of which the indebtedness was incurred; (2) property subject to depreciation or depletion; (3) property against which the indebtedness was a hen; (4) other property except inventory, notes and accounts receivable and money; and (5) inventory and receivables.

It is to be noted that the aggregate basis reduction is equal to the amount of income which is not recognized solely by virtue of the election under section 108. If part of the gain realized from the cancellation is not recognized for some other reason, such as insolvency, the amount of basis reduction under the election provisions will be similarly limited.

A further problem exists under section 108 if the debtor transfers property to the creditor in compromise of the obligation. We have seen earlier that in such a case the transaction is not divided into two parts-satisfaction of part of the obligation and cancellation of the balance-but that the debtor's entire gain is capital if the transferred property is a capital asset in his hands. ${ }^{109}$ From this analysis it would seem to follow that none of the debtor's gain is cancellation of indebtedness income. This result, however, is not clear. The already confused picture is further inuddled by the fact that the regnlations under section 1017 provide that where the discharge is accompanied by a transfer of property by the debtor, the difference be-

105 Denman Tire \& Rubber Co, 14 T.C. 706 (1950), aff'd, 192 F.2d 261 (6th Cir. 1951); Spear Box Co., 13 T.C. 238 (1949), aff'd, 182 F.2d 844 (2d Cir. 1950); Marshall Drug Co. v. United States, 118 Ct. Cl. 532, 95 F. Supp. 820 (1951), cert. denied, 341 U.S. 948 (1951). But see Reynolds v. Boos, 188 F.2d 322 (8th Cir. 1951).

${ }^{108}$ This includes both property owned at the time of the cancellation and property acquired thereafter. INT. REv. CODE of 1954, \& $101 \%$.

107 Id. $\$ \$ 108$ (a) (2), 1017.

108 Treas. Regs. $\$ \$ 1.1017-1,1.1017-2$ (1956).

109 See text following note 76 supra. 
tween the full amount of the discharged obligation and the market value of the transferred property constitutes cancellation of indebtedness income. ${ }^{110}$ Presumably any difference between the debtor's basis for the transferred property and its market value would be capital gain or loss. ${ }^{111}$

It is to be recalled that the Board of Tax Appeals has held that the entire gain arising from a transfer of a capital asset in compromise of an obligation is capital gain. ${ }^{112}$ Furthermore, the Tax Court, in holding that the entire gain from such a transaction is subject to the insolvency rule, has failed to divide the transfer and compromise into its component parts. ${ }^{113}$ And the Supreme Court, in himiting the theory of the American Dental case, has refused to divide a compromise transaction into its component parts so as to find a gift to the debtor of the amount cancelled. ${ }^{114}$ In view of this consistent failure or refusal to divide a compromise transaction into two parts-satisfaction of part of the obligation and cancellation of the balance- the validity of the regulation providing for such a division under section 108 is doubtful. If the prior cases are followed in one arising under sections 108 and 1017, the result will be that no cancellation of indebtedness income will be found if the compromise is accompanied by a transfer of property from the debtor to the creditor. Thus, the election provisions of section 108 would not be available to the debtor in such a case. ${ }^{115}$

Another interesting aspect of section 108 deserves some attention. As noted above, in order to achieve nonrecognition under section 108 of cancellation of indebtedness income, the debtor must adjust the basis of his property. ${ }^{116}$ This raises the question whether this nonrecognition provision may result in the conversion of ordinary income into capital gain. Consider the following example: $D$ corporation borrows $\$ 100,000$ from $C$ and uses the money to purchase Blackacre, a capital asset. $D$, which is not insolvent, later compromises the debt for a cash payment to $C$ of $\$ 80,000^{117}$ and elects under section 108. Pursuant to section 1017, D's basis for Blackacre is reduced from $\$ 100,000$ to $\$ 80,000 .^{118} \mathrm{D}$ subsequently sells Blackacre for

110 Treas. Reg. $\$ 1.1017-1$ (b) (5) (1956).

111 This assumes the existence of a capital asset.

112 Peninsula Properties Co., 47 B.T.A. 84 (1942), acq., 1942-2 CoM. BuLr. 14, discussed in text following note 76 supra.

113 Main Properties, Inc., 4 T.C. 364 (1944), acq, 1945 Cuns. BuLc. 5, discussed in text following note 91 supra.

114 Coumissioner v. Jacobson, 336 U.S. 28 (1949), discussed in text following note 103 supra.

115 Of course, if the Commissioner stands by his regulation the issue is not likely to be raised since a debtor who wants to take advantage of the election under $\S 108$ would not challenge Treas. Reg. \$1.1017-1(b)(5) (1956).

116 Text at note 107 supra.

117 Assume that no part of the $\$ 20,000$ difference is a gift from $C$ to $D$.

118 Treas. Regs. $\S 1.1017-1$ (a) (1), 1.1017-1(b) (2) (1956). 
$\$ 120,000$. What is the extent and nature of the gain realized by $D$ corporation from the sale?

The statute and regulations are silent on this point. At first glance, however, it would seem that $D$ 's entire gain of $\$ 40,000$ is capital gain. If so, the section 108 election provides a method of converting ordinary income into capital gain.

However, the answer is not as obvious as it may seem. It is quite possible that a court faced with this issue would apply a variation of the tax benefit rule $\mathrm{e}^{119}$ and hold that the gain from the sale of Blackacre is ordinary income to the extent that it is attributable to the basis reduction under section 1017. In reaching such a conclusion a court could rely upon the fact that, as to the creditor under the tax benefit rule, a capital asset ceases to be such to the extent that its basis has been written off with a tax benefit. ${ }^{120}$ If such a theory were adopted, $D$ in the above example would realize $\$ 20$,000 ordinary income and $\$ 20,000$ capital gain from the sale of Blackacre.

Even assuming, however, that in the above example the entire $\$ 40,000$ is capital gain, the potential of the section 108 election for converting ordinary income into capital gain is restricted by two other factors. First, the basis reduction may be allocated to non-capital assets, ${ }^{121}$ in which case gain from the subsequent sale will be ordinary income even if the tax benefit theory is not adopted. ${ }^{122}$ Second, to the extent that the basis reduction is allocated to property subject to depreciation or cost depletion, part of the potential capital gain from a subsequent sale will be offset by smaller depreciation or depletion deductions.

\section{Cancellation as Reduction of Cost}

Under certain circumstances cancellation of indebtedness constitutes a reduction of the purchase price of property rather than taxable income to the debtor. ${ }^{123}$ Although the cases are not in unanimity, there are three factual situations in which such a result has been reached.

First is the situation where the debtor who has incurred an obligation in the purchase of property negotiates with the creditor-vendor to adjust the purchase price. The intention of the parties that the reduction of the debt is an adjustment of purchase price will be given effect ${ }^{124}$ and there

110 Discussed with regard to creditors in text following note 28 supra.

120 First National Bank of Lawrence County, 16 T.C. 147 (1951), discussed in text at note 38 supra.

121 See Treas. Regs., $\$ \$ 1.1017-1,1.1017-2$ (1956), for the order in which the aggregate basis reduction is allocated to the debtor's property.

122 This assumes also that INT. REv. CODE OF $1954, \S 1231$ is inapplicable.

123 Cf. INT. REv. CODE of 1954, \& 108.

124 Borin Corp. v. Commissioner, 117 F.2d 917 (6th Cir. 1941), cert. denied, 314 U.S. 638 (1941) ; Pinkney Packing Co., 42 B.T.A. 823 (1940), acq., 1941-1 Cum. Burx. 8; Cherokee Co., 41 B.T.A. 1212 (1940), acq., 1940-2 CuM. BuLr. 2. 
will be no cancellation of indebtedness income to the debtor, but his basis for the purchased property must, of course, be reduced accordingly.

Next is the situation where the taxpayer has acquired property subject to an indebtedness for which he is not personally liable. In such a case a reduction of the debt is not income to the taxpayer but constitutes a reduction of his purchase price for the property ${ }^{125}$ and a corresponding reduction in his basis. ${ }^{128}$.

Third is the situation in which the taxpayer is personally liable for the indebtedness. It has been held that the debtor, even though personally liable, realizes no taxable income from the reduction of a debt incurred in the purchase of property if the amount of the debt before reduction is equal to or greater than the then value of the purchased property. ${ }^{127}$ In such a case the debtor must reduce his basis for the property in the same amount that the debt is reduced..$^{128}$

As noted, one of the requirements for the applicability of this rule is that the debt which is being reduced be incurred by the debtor in the purchase of property. The rule has been applied to a case involving reduction of a bank loan the proceeds of which were used to purchase property. ${ }^{129}$ The rule has not been applied, however, to the reduction of a mortgage debt which was placed on the property after its acquisition by the debtor. ${ }^{130}$

125 Ernst Kern Co., 1 T.C. 249 (1942), acq., 1946-2 CuMr. Bunc. 3 (withdrawing prior non-acq., 1944 Cum. Bult. 42) ; Hotel Astoria, Inc., 42 B.T.A. 759 (1940), acq., 1940-2 CuMr. BuLL. 4; P.J. Hiatt, 35 B.T.A. 292 (1937), acq., 1937-1 Cum. Bur.. 12; Fulton Gold Corporation, 31 B.T.A. 519 (1934). But see Commissioner v. Stanley Co. of America, 185 F.2d 979 (2d Cir. 1951), reversing 12 T.C. 1122 (1949); Mendham Corporation, 9 T.C. 320 (1947).

This rule does not apply if the encumbered property is transferred to the creditor in discharge of the obligation. In such a case the lack of personal liability of the transferor has no bearing on whether and to what extent he realizes taxable gain or loss. See Parker v. Delaney, 186 F.2d 455 (1st Cir. 1950), cert. denied, 341 U.S. 926 (1951). Cf. text following note 143 infra.

126 Fulton Gold Corp., 31 B.T.A. 519 (1934). Quaere as to the results if the cancelled portion of the debt exceeds the taxpayer's basis for the property, perbaps because of depreciation deductions. See note 143 infra. Cf. Lutz \& Schramm Co., 1 T.C. 682 (1943), non-acq., 1943 Cus. Buxr. 35.

127 Hirsch v. Commissioner, 115 F.2d 656 (7th Cir. 1940); Helvering v. A. L. Killian Co., 128 F.2d 433 (8th Cir. 1942), affirming 44 B.T.A. 169 (1941); Gehring Publishing Co., 1 T.C. 345 (1942), acq., 1943 Cum. Bull. 9. But see Fifth Ave.-14th St. Corp. v. Commissioner, 147 F.2d 453 (2d Cir. 1945) ; Frank v. United States, 131 F.2d 864 (3d Cir. 1942), affirming per curiam, 44 F. Supp. 729 (E.D.Pa. 1942).

128 Hirsch v. Commissioner, 115 F.2d 656 (7th Cir. 1940). See the quaere in note 126 supra, as to the result if the cancelled portion of the debt exceeds the debtor's basis for the property.

129 Charles L. Nutter, 7 T.C. 480 (1946), acq., 1946-2 Cuar. Burc. 4. But see Edward W. Edwards, 19 T.C. 275 (1952), acq., 1953-1 Cum. BurL. 4. The distinction between these two cases seems to be that in Nutter the purchased property was pledged as security for the bank loan, the pledge making the loan more in the nature of a purchase money obligation than it otherwise would be.

130 Mendham Corp., 9 T.C. 320 (1947). 
Such a transaction cannot be characterized as a reduction in the purchase price of the property since the subsequent mortgage debt has no relationship to purchase price. ${ }^{131}$

The other requirement already mentioned is that the current market value of the property inust not be greater than the balance due on the debt before reduction. Where the market value of the property was $\$ 20,000$ and the full balance due on the debt was $\$ 19,250$, cancellation of the mortgage debt for a cash payment of $\$ 12,000$ did not meet this market value requirement. Accordingly, the debtor was held to have realized cancellation of indebtedness income in the amount of $\$ 7,250 .^{132}$

If in the above case the market value of the property had been $\$ 12,000$ or less, the debtor would have realized no taxable income from the cancellation but his basis for the property would be reduced by $\$ 7,250 .^{183}$ But what would be the result if the market value of the property had been $\$ 15,000$ and the $\$ 19,250$ debt were cancelled for a cash payment of $\$ 12$,000 ? The answer to this question depends upon whether the amount of the debt remaining due after the reduction must be equal to or greater than the market value of the property. We have seen that the market value of the property must not be greater than the full balance of the debt before reduction. No cases have been found, but three different opinions have been expressed as to the tax result if the amount of the debt after reduction is less than the value of the property.

One opimion is that the relation between market value and the balance of the debt after reduction is immaterial and that the entire reduction of the purchase money obligation will be tax free if the unreduced debt exceeds market value. ${ }^{134} \mathrm{~A}$ second opinion is that if market value exceeds the debt as reduced, cancellation of indebtedness income is realized to the extent of that excess but the difference between the unreduced debt and market value is not taxable income to the debtor. ${ }^{135}$ The third opinion is that if market value exceeds the debt as reduced, the entire amount of the reduction is cancellation of indebtedness income even though the unreduced debt exceeded market value. ${ }^{138}$

Applying these three possibilities to the above example of a $\$ 19,250$ purchase money obligation being cancelled for $\$ 12,000$ in cash when the

131 Unlike a purchase money obligation, a subsequent mortgage debt has no effect upon the debtor's basis for the property.

132 L. D. Coddon \& Bros, 37 B.T.A. 393 (1938).

133 See cases cited at note 127 supra.

1342 Research Institute of America, Federat Tax Coozdinator, II J-7401, p. 30,143 (1960).

135 See 2 Rabkin \& Johnson, Federat Income, Gift and Estate Taxation, \& 36.05(2) (1954). Cf. text at notes 112-14 supra, discussing other situations where a compromise transaction has not been divided into two parts.

1361 CCH 1960 Stand. Fed. TAX Rep. $\| 670.019$. 
property has a market value of $\$ 15,000$, the following results would be reached: (1) Under the first possibility, the entire reduction would be taxfree and the debtor's basis would be reduced by $\$ 7,250$; (2) under the second possibility, the debtor would realize cancellation of indebtedness income in the amount of $\$ 3,000^{137}$ and his basis would be reduced by $\$ 4,250 ;^{138}$ while (3) under the third possibility the debtor would realize cancellation of indebtedness income in the amount of $\$ 7,250$ and his basis would remain unchanged.

In evaluating these three possibilities, the first seems the most likely to be correct. First, the rule is stated in terms of a purchase money debt which exceeds market value of the property before reduction. ${ }^{139}$ Furthermore, at least one court applying the rule failed even to make a finding of the market value of the property, being content with the fact that market value was less than the debt before reduction. ${ }^{140}$ This tends to indicate that the relationship between market value and the balance of the debt after reduction is immaterial, thus discrediting both the second and third possibilities but especially the third since under that possibility the entire reduction would be taxable gain if market value exceeded the debt as reduced. The second possibility is also made doubtful by the fact that, as we have seen earlier, debt compromises under other circumstances have not been divided into two parts but have been treated as a single transaction. ${ }^{141}$

However, the reason that cancellation of indebtedness income is not recognized if the unreduced obligation exceeds market value of the property is that a reduction of the debt under such circumstances is an adjustment of the purchase price of the property. In effect, the parties are agreeing that the original purchase price was too high. This reasoning has logic if the debt is reduced to an amount equal to or greater than market value of the property, but it loses its forcefulness ${ }^{142}$ if the debt is reduced below that amount. Since the rationale for the nonrecognition rule is not present in such a case, it may well be that the correct result is that cancellation of indebtedness income is recognized to the extent that the debt is reduced below the current market value of the property. ${ }^{143}$

137 The excess of market value over the debt as reduced

138 The difference between the debt before reduction and market value of the property. 139 See text at note 127 supra.

140 Gehring Publishing Co., 1 T.C. 345, 354 (1942), acq., 1943 Cun. Buxz. 9.

141 See text at notes 112-14 supra.

142 Except, perhaps, to the extent that previous payments on the obligation have made it more nearly equal to the depressed market value of the property.

143 The debtor's basis for the property is reduced to the extent that his gain from reduction of the debt is tax-free. If the non-taxable debt reduction exceeds his basis, perhaps because of prior depreciation deductions, the theory advanced in the text could be used to argue that the excess of debt reduction over basis constitutes taxable income. It would be difficult to say that a drop in market value caused by ordinary depreciation motivated the creditor-vendor to adjust the purchase price. But cf. the American Dental case, discussed in text at note 101 supra, where the Court found a gift despite a prior tax benefit. 
It should be noted that the value depreciation theory under discussion may apply to a situation where the debtor transfers the purchased property to the creditor-vendor in compromise of the debt. ${ }^{144}$ No cancellation of indebtedness income is realized by the debtor-vendee, but, of course, there is no basis reduction because the debtor no longer owns the property in question. But is any gain or loss realized by the debtor-vendee if his basis for the purchased property varies from its market value at the time of the transfer? In Charles L. Nutter, ${ }^{145}$ the purchase money debt of $\$ 84,000$ was cancelled by the transfer of the purchased property to the creditor. The value of the property at that time was $\$ 12,800$ and the debtor's basis was $\$ 77,000$. The debtor claimed that no cancellation of indebtedness income was realized because of the value depreciation theory but that he had realized a capital loss of $\$ 64,200$, that amount being the excess of basis over value. The Commissioner contended that the debtor had realized taxable gain of $\$ 7,000$, that being the difference between his basis for the property and the total balance of the debt. ${ }^{146}$ The Tax Court held that the transaction was covered by the value depreciation theory and that no gain or loss was realized by the debtor. In effect, therefore, the court held that if the value depreciation theory is applicable it applies to the entire transaction and prevents the recognition of any gain or loss. This reasoning seems to be equally applicable to prevent recognition of any gain in a case where basis is less than market value of the purchased property. ${ }^{147}$

\section{Corporation-shareholder Relationship}

Other variations on the general rule of cancellation of indebtedness income exist if the debtor and creditor stand in a corporation-shareholder relationship.

Forgiveness by a shareholder-creditor of the corporation's debt to him ordinarily is a contribution to the capital of the corporation. ${ }^{148}$ Consequently, the corporation realizes no taxable income from the forgiveness. ${ }^{140}$ This is true even though the forgiven debt is related to a deduction from which the corporation realized a previous tax benefit. ${ }^{150}$ Apparently no adjust-

144 Charles L. Nutter, 7 T.C. 480 (1946), acq., 1946-2 CuM. Bull. 4. See also, Gehring Publishing Co., 1 T.C. 345, 354 (1942), acq., 1943 CuM. Burx. 9. Cf. note 125 supra.

1457 T.C. 480 (1946), acq., 1946-2 Cum. BuLL. 4.

146 The Commissioner did not contend that this gain was ordinary cancellation of indebtedness income but rather that it was capital gain. This accords with the rule that a conveyance by a mortgagor to the mortgagee in cancellation of the debt is a capital transaction. See text following note 75 supra.

147 Cf. note 143 supra.

148 Treas. Reg. §1.61-12(a) (1957); Pancoast Hotel Co., 2 T.C. 362 (1943), acq., 1943

CUM. BULL. 18.

149 INT. REv. CoDE of 1954, § 118; Pennsylvania Electric Company v. United States, 133 Ct. Cl. 314, 135 F. Supp. 416 (1955).

150 Pancoast Hotel Co., 2 T.C. 362 (1943), acq., 1943 Cunr. Burr. 18. Cf. text at notes 
ment to the basis of corporate property is required by virtue of the forgiveness even though the debt was incurred by the corporation in the purchase of property from the shareholder. ${ }^{151}$

The regulations recognize this capital contribution rule, but state that the forgiveness constitutes a capital contribution "to the extent of the principal of the debt."152 At least one case has distinguished principal from interest, ${ }^{153}$ but normally once interest becomes due it loses its character as such and is treated as principal. At any rate, it is doubtful that this capital contribution theory is limited to principal. ${ }^{154}$

This rule may apply even though the creditor was not a shareholder prior to the cancellation. A corporation realizes no gain or loss from the issuance of its stock in compromise of its obligation. The amount of the forgiveness by the creditor is a contribution to the corporation's capital. ${ }^{155}$

Forgiveness by a corporation of a debt owed it by a shareholder ordinarily constitutes a dividend to the shareholder-debtor if the corporation has sufficient earnings and profits. ${ }^{156}$ The effect of this rule is that the question of whether the shareholder-debtor has realized income from the cancellation is determined just as if he were any other debtor, but the character of that income and the amount which will be recognized is governed by the rules relating to corporate distributions.

If the corporation has no earnings and profits, the amount forgiven is a return of capital and reduces the shareholder's basis for his stock. This apparently is true even though the forgiveness would have given rise to ordinary income if the debtor had not been a shareholder of the creditor.

Normally, the amount of cancellation income realized by a debtor is measured by the face amount of the discharged obligation. However, if the debtor is a shareholder of the creditor, the cancellation-dividend income is measured by the fair market value of the discharged obligation. ${ }^{157}$ The reason is that the forgiveness is treated as a corporate distribution of prop-

151 Greer v. Commissioner, 230 F.2d 490 (5th Cir. 1956), reversing 20 T.C. 690 (1953). Cf. text at note 128 supra.

Note that property contributed to the capital of a corporation by a shareholder has the same basis to the former as it had to the latter. INT. REv. CODE of 1954, §362 (a).

152 Treas. Reg. § 1.61-12 (a) (1957).

153 Helvering v. Jane Holding Corp., 109 F.2d 933 (8th Cir. 1940), cert. denied, 310 U.S. 653 (1940).

154 See Helvering v. American Dental Co., 318 U.S. 322 (1943), which approved the capital contribution rule without limiting it to principal.

155 See INT. Rev. CoDE of 1954, \$§ 118, 1032; Estate of L.W. Mallory, 27 B.T.A. 750 (1933), non-acq., XH-2 CuMr. BuLL. 22. But see G.C.M. 22528, 1941-1 CuM. BuLI. 193; H.R. REP. No. 855, 76th Cong., 1st Sess. 25 (1939).

156 Allen v. Commissioner, 117 F.2d 364 (1st Cir. 1941); Hudson v. Commissioner, 99 F.2d 630 (6th Cir. 1938), cert. denied, 306 U.S. 644 (1939); Wilputte Coke Oven Corporation, 10 T.C. 435 (1948).

157 See Commissioner v. Kellogg, 119 F.2d 115 (9th Cir. 1941). 
erty to the shareholder-debtor, the property being the claim against him. ${ }^{158}$ The taxable dividend to the debtor is equal to the fair market value of this property. ${ }^{158}$

This rule that forgiveness by the corporation-creditor is a corporate distribution to the stockholder-debtor leads to the conclusion that a claim distributed to the debtor in liquidation of the corporation does not give rise to ordinary dividend income. Such a case does not involve a cancellation of an indebtedness. It is a liquidation distribution, the tax treatment of which is governed by the corporate liquidation provisions of the Code. ${ }^{100}$

It is probable also that this rule would be superseded by the adjustment of purchase price theory if the shareholder's debt to the corporation were incurred in the purchase of his stock and the current market value of the stock were less than the balance due on the debt. ${ }^{101}$ Such a situation probably would be a tax-free purchase price adjustment rather than a dividend arising froin cancellation of indebtedness. ${ }^{182}$

\section{CONCLUSION}

We have seen that the general rules relating to taxation of collections by a creditor are that the creditor realizes and is taxable on ordinary income if collections exceed his basis for his claim and that he is entitled to a bad debt deduction if his basis exceeds collections. There are several exceptions to the general rules, one of which provides that the creditor's gain or loss may be capital rather than ordinary in the case of retirement of a corporate obligation. In addition, the double-barreled tas benefit rule may provide on the one land for the nonrecognition of what otherwise would be ordinary income and, on the other land, for the taxation as ordinary income of amounts which otherwise would constitute capital gains. Finally, collections may constitute capital gain rather than ordinary income if the creditor's claim had no ascertainable market value when acquired by him.

The debtor who satisfies an obligation with property is engaging in an exchange and his gain or loss will, under the general rule, be capital in nature if a capital asset is involved. If the transferred property has been

158 Ibid. If the debtor-shareholder also is a corporation, the $35 \%$ intercorporate dividend deduction presumably would be available if INT. REv. CoDE of 1954, $\$ 243$ (a) were otherwise applicable.

150 INT. REv. CODE OF 1954, \&301(b). But see $\$ 301$ (b) (1)(B) in the case of a debtorshareholder which also is a corporation. Quaere as to the result if the claim cannot be valued. Compare the Carter rule, discussed in text following note 44 supror.

160 James J. Gravley, 44 B.T.A. 722 (1941), acq., 1941-2 Com. Burl. 6; Estate of Helen Gilmore, 40 B.T.A. 945 (1939), acq., 1940-1 CuM. Bulx. 2.

101 The purehase price adjustment theory is discussed in text following note 127 supra.

162 See Commissioner v. Johnson, 131 F.2d 709 (6th Cir. 19.42), affirming 43 B.T.A. 960 (1941), non-acq., 1941-1 CuM. BuLL. 16. Although decided on a somewbat different point, this case infers that the purchase price adjustment rule supersedes the corporate distribution theory. 
used in the debtor's trade or business, the gain or loss will be governed by section 1231. Likewise, the debtor who transfers a capital asset or a section 1231 asset to his creditor in compromise of the debt realizes capital gain or loss or section 1231 gain or loss measured by the difference between his basis for the transferred property and the full amount of his obligation. But the debtor who is discharged from his obligation without transferring any property to his creditor realizes income in the amount of the cancelled portion of the debt. This income generally is recognized and taxable to the debtor as ordinary income. But the debtor's gain or income may escape taxation-at least for the present-if the debtor is insolvent, if he elects to reduce his basis for property owned by him or if the cancellation is a gift from the creditor. Under certain circumstances a reduction in the debtor's obligation may be an adjustment of the purchase price of property rather than cancellation of indebtedness income. In addition, special rules apply to cancellations and compromises if there is a corporationshareholder relationship between the debtor and creditor. 